\title{
高アスペクト比翼のモデル修正と能動フラッタ抑止*1 Model Modification of a High-Aspect-Ratio Aeroelastic Wing and Active Flutter Suppression
}

\author{
藤 森 篤*2 松 下 洸*3 ・齊 藤 健 一*3 ・ 安 藤 泰 勝*4 \\ Atsushi Fujimori, Hiroshi Matsushita, Ken'ichi SaItoH and Yasukatsu ANDo
}

Key Words : Active Flutter Suppression, Model Uncertainty, Unsteady Aerodynamic Force, Wind Tunnel Test

\begin{abstract}
This paper presents a model modification of a high-aspect-ratio aeroelastic wing and active flutter suppression. One of uncertainties in linear models of the aeroelastic wing in the transonic region is included in the unsteady aerodynamic force which is represented by a linear function. To reduce the uncertainty, the linear model of the aeroelastic wing is modified in terms of the unsteady aerodynamic force so that the flutter pressure of the linear model coincides with the one obtained by the wind tunnel test. Using the modified linear model, controllers are then designed by $H_{\infty}$ synthesis for the active flutter suppression. The control performance is evaluated by the wind tunnel test.
\end{abstract}

\section{1. 緒 言}

大型航空機の超音速化，高性能化を目指した超音速輸送 機（supersonic transport: SST）プロジェクトが. 米国 およびヨーロッパで進められている1,2)。日本においても 次世代超音速機の開発に関する調查研究を受けて，小型超 音速実験機計画とその要素技術の研究が航空宇宙技術研究 所を中心に行われている3).SST は，重量の軽減化に伴い 翼剛性が低下する傾向にある，遷音速領域では，フラッタ 動圧が急激に低下する「遷音速ディップ」なる現象が知ら れており，上記の低剛性化は遷音速域においてフラッタ発 生の危険性を高めている。それゆえ, SSTの要素技術の 一つとして，遷音速領域でのフラッタ回避のための能動制 御が必要であると考えられている4)。高アスペクト比翼を 用いた遷音速での能動フラッタ抑止 (active flutter sup pression：AFS) に関する研究が, Saitohらによって報 告されている ${ }^{5 \sim 8)}$ 。そこでは，高アスペクト比翼の線形モ デルを構成し，ロバスト制御系設計法を適用して安定化コ ントローラを設計し，その制御効果を線形モデルおよび風 洞実験によって険証している。しかしながら，線形モデル と風洞実験での制御結果には大きなずれがあり，この原因 の一つとして、制御系設計で用いた高アスペクト比翼の線 形モデルに含まれているモデル化誤差が風洞実験での制御 性能を劣化させていることが考えられる．フラッタ㧕止を より向上するロバストなコントローラを設計するために は，このモデル化誤差をできるだけ少なくしたモデルを構

\footnotetext{
${ }^{* 1}$ 平成 11 年 10 月 13 日, 第 37 回飛行機シンポジウムにて発表. 平成 12 年 3 月 2 日原稿受理

*2 静岡大学工学部機械工学科

*3 航架等宙技街研究所

*4 航空宇宙技街振興財団

*5 翼中央部の膨らみは，サーボモータを内蔵するためのスペース 確保によるものてある。
}

成する必要がある。

そこで本研究は，モデル化誤差の1つである非定常空気 力の見積り誤差を低減するために、コントローラの設計ポ イントだけでなく動圧を増加させたときの不安定領域にお いても蛔洞実験での特性值に近づけるようにモデル修正を 行う方法を提案する。具体的には，不安定領域での高アス ペクト比翼の線形モデルの特性が，風洞実験で得られるも のと一致するようにフラッタ制御実験を介してモデル修正 を行う。この修正により,フラッタ動压よりも高い動圧で 高アスペクト比翼の線形モデルがより正確に表されるの で，それを用いて設計された AFS 制御系はフラッタ抑止 効果を高めることが期待できる. 本研究ではさらに, 修正 した線形モデルを用いて $H_{\infty}$ 制御法により AFS コントロ 一ラを設計し，その制御性能を線形モデルおよび風洞実験 により評価する。

\section{2. 高アスペクト比翼の線形モデル}

本研究で使用した高アスペクト比翼を第 1 図に示す。こ の翼は民間航空機の翼形状をスケールダウンきせたもの で, 翼スパン長は $1043[\mathrm{~mm}]$ ，翼根でのコード長が 369 $[\mathrm{mm}]$ ，翼端では $101[\mathrm{~mm}]$, 約 $17[\mathrm{deg}]$ の後退角が付け られている，翼の状態を測定するセンサは，曲げや挍りを 計測するために 7 力所に歪ゲージが張られている．また， 4 力所に加速度計を取り付けている。制御舵面として, 前 縁舵面 $\delta_{1}$ と後縁舵面 $\delta_{2}$ を装備して抢り, 翼に内藏されて いる 2 つ高性能の ACサーボモータによりそれぞれ独立 に駆動することができる゙5.本研究では，制御舵面として 後緑舵面のみを用いる。また，AFS 制御系設計では加速 度計 $a_{2}$ を翼の出力として使用する。

翼の弾性変形を $N$ 個の振動モード $\xi \in \Re^{N}$ と後縁舵面 $\delta_{2}$ $\in \mathfrak{R}^{1}$ にっって表現すると, 高アスペクト比翼の空力弾性 方程式は 


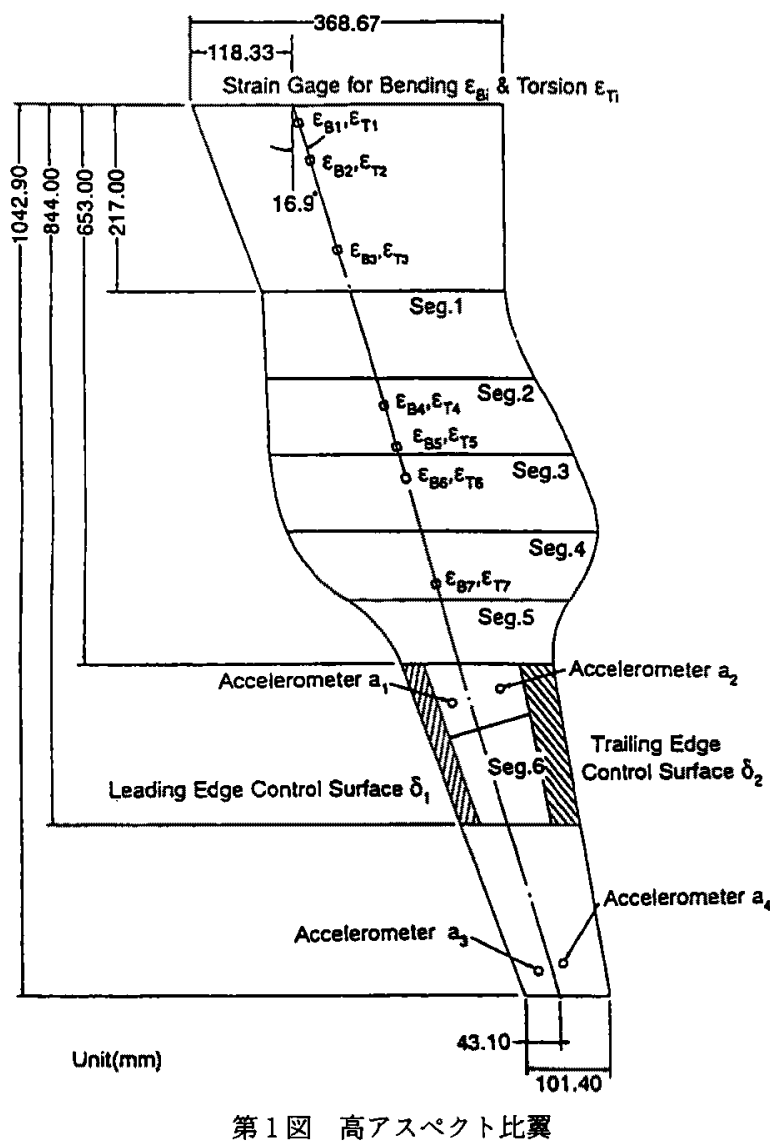

第 1 図＼cjkstart高アスペクト比翼

$$
M \ddot{\xi}(t)+D \dot{\xi}(t)+K \xi(t)+S \ddot{\delta}_{2}(t)=F(q)
$$

と表せる5).ただし， $M, D, K \in \Re^{N \times N}$ は主翼部の質量行 列, 減衰行列おるび剛性行列である. $S \in \Re^{N \times 1}$ 汹制御舵 面の質量行列， $F(q) \in \Re^{N}$ は翼の運動に伴う非定常空気力 ベクトルで動圧 $q$ の関数である. 本研究では, 低周波か ら 4 つの振動モードを考慮して線形モデルを導出する $(N$ =4). その固有振動数を第 1 表に示す.

高アスペクト比翼の線形モデルを得るためには，(1)式 右辺の空気力 $F(q)$ を $\xi や \delta_{2}$ に関して線形となるように 近似しなければならない。この近似はさまざまな方法があ るが，本研究は DPM (Doublet Point Method)"で求め た空気力を次式によって近似する。

$$
\begin{aligned}
F(q)= & A_{2 \xi} \ddot{\xi}+A_{2 \delta} \ddot{\delta}_{2}+\sqrt{q} A_{1 \xi} \dot{\xi}+\sqrt{q} A_{1 \delta} \dot{\delta}_{2} \\
& +q A_{0 \xi} \xi+q A_{0 \delta} \delta_{2}+r \\
\dot{r}=\Lambda r & +q^{3 / 2} B_{0 \xi} \xi+q^{3 / 2} B_{0 \delta} \delta_{2}
\end{aligned}
$$

$A_{i \xi}, A_{i \delta}, B_{0 \xi}, B_{0 \delta}$ は空気力係数行列, $r \in \Re^{N}$ は非定常 空気力の遅れを表す補助変数， $\Lambda \in \Re^{N \times N}$ はその時定数を 集めた行列である。

舵面の駆動系のダイナミックスは次の 2 次系モデル

$$
\ddot{\delta_{2}}+2 \zeta \omega_{n} \dot{\delta}_{2}+\omega_{n}^{2} \delta_{2}=\omega_{n}^{2} \delta_{c}+w
$$

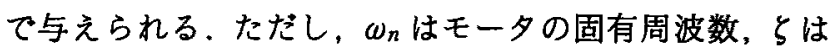
減衰係数， $\delta_{c}$ は指令舵角， $w$ はモー夕に混入する白色外 乱である。モータの周波数応答の測定結果より， $\omega_{n}=314$ $[\mathrm{rad} / \mathrm{s}], \zeta=0.7$ てある. フラッタ制御の風洞実験では制 御則の実行にディジタルコンピュータを用いるので，加速

\begin{tabular}{cc} 
第 1 表 & \multicolumn{2}{c}{ 高アスペクト比翼の固有 } \\
\multicolumn{2}{c}{ 振動モード } \\
\hline 振動モード & 固有振動数 $[\mathrm{Hz}]$ \\
\hline 1st & 13.1 \\
2nd & 35.7 \\
3rd & 44.6 \\
4th & 85.0 \\
\hline
\end{tabular}

度計の出力に対するアンチエリアッシングフィルタのダイ ナミックスと $\mathrm{A} / \mathrm{D}$ 変換の時間遅れを考慮する必要があ る.それらを 1 次系モデル

$$
\begin{aligned}
& G_{f}(s)=\frac{\omega_{f}}{s+\omega_{f}} \\
& G_{d}(s)=\frac{s-\omega_{d}}{s+\omega_{d}}
\end{aligned}
$$

で与える， $G_{f}(s)$ の遮断周波数 $\omega_{f}$ は翼模型とディジタル コンピュータを接続したときに発生する 4 次モード付近の 振動を低減するために, $\omega_{f}=471[\mathrm{rad} / \mathrm{s}](=75[\mathrm{~Hz}])$ と した。また $G_{d}(s)$ の折点周波数 $\omega_{d}$ は、ディジタルコンピ ュータでのサンプリングを $500[\mathrm{~Hz}] て ゙$ 行うことより，そ の 2 倍の $\omega_{d}=6283[\mathrm{rad} / \mathrm{s}](=1000[\mathrm{~Hz}])$ と与えた.

(1)〜（6)式をすべてまとめると，高アスペクト比翼全 体の状態空間表現モデルは次の 1 入力 1 出力 16 次元線形 パラメー夕可変 (linear parameter varying: LPV) シス テムとなる。

$$
\begin{aligned}
& \Sigma(q):\left\{\begin{array}{l}
\dot{x}(t)=A(q) x(t)+B(q) u(t)+B_{n} w(t) \\
y(t)=C(q) x(t)+D(q) u(t)+v(t)
\end{array}\right. \\
& x(t) \triangleq\left[\begin{array}{llllll}
\xi^{\mathrm{T}} & \delta & \xi^{\mathrm{T}} & \dot{\delta} & \gamma^{\mathrm{T}} & \eta^{\mathrm{T}}
\end{array}\right]^{\mathrm{T}} \in \Re^{16}, \\
& u(t) \triangleq \delta_{c}(t) \in \mathfrak{R}^{1}, \quad y(t) \triangleq a_{2}(t) \in \Re^{1}
\end{aligned}
$$

$v(t)$ は加速度計に混入する白色ノイズ, $\eta \in \mathfrak{R}^{2}$ は $G_{f}(s)$ と $G_{d}(s)$ を状態空間表現した際の状態変数である.より 詳細な状態空間表現モデル導出の説明は文献 10）を参照さ れたいる。

\section{3. 線形モテルの修正}

本節では，前節で求めた高アスペクト比翼の LPV シス テム(7)式のモデル修正について述べる．まず，本研究で 着目しているモデル化㕵差の要因である非定常空気力表現 に対して修正係数を導入し，次にLPV システムが風洞実 験での翼特性と合うようにその修正係数を決定する風洞実 験について述べる.

3.1 空気力の修正係数 以前に行われたSaitohらの

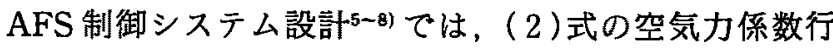
列が一定であるとした非定常空気力を用いて（7)式を扱っ ていた，しかしながら，(2)，(3)式はDPMにより求め た空気力を $\xi, \delta_{2}$ やその微分に関して線形近似した表現て あり，さらに DPM 自体が亚音速域の空気力の計算方法て あるため，遷音速域で空気力を正確に表現しているとは いえない，そこで本研究では，(2)，（3）式の空気力表現 に誤差があることを考虑して，遷音速域で DPM より求め た (2)，（3)式の空気力係数行列を次式のように修正する ことを提案する. 


$$
\begin{gathered}
\tilde{A}_{i \ell}=A_{i \varepsilon} r_{f}(q), \quad \tilde{A}_{i \delta}=A_{i \delta} r_{f}(q) r_{s}(q) \\
(i=0,1,2) \\
\tilde{B}_{0 \ell}=B_{0 q} r_{f}(q), \quad \tilde{B}_{08}=B_{08} r_{f}(q) r_{s}(q)
\end{gathered}
$$

$r_{s}(q) ， r_{s}(q)$ は翼全体および舵面に対する修正俰数で、動 压 $q$ に依存する。このとき，LPV システム $(7)$ 式の安定 限界が風洞実験での安定限界, すなわち, 実際にフラッ夕 が発生するときの動圧と一致するように修正係数 $r_{f}(q)$, $r_{8}(q)$ を決定する. 本研究では, 次の 3 種類の係数決定法 を検討する。

Case-a：主翼部の空気力係数は一定值, 舵面部の空気力 係数が動圧 $q$ に依存.

$$
r_{f}(q)=r_{f_{0}}(=\text { const }), \quad r_{s}(q)=\text { varying }
$$

Case-b : 空気力係数全体が動圧 $q$ に依存.

$$
r_{f}(q)=\text { varying, } \quad r_{s}(q)=1
$$

Case-c : 主翼部の空気力係数が動圧 $q$ に依存, 舵面部は 一定.

$$
r_{f}(q)=\text { varying, } \quad r_{s}(q)=\frac{r_{s_{0}}}{r_{f}(q)}
$$

これらのうちで，修正係数の特性が動圧に関して一律の特 性となっているケースをモデル修正に採用する。

3.2 修正係数の決定方法 前節で述べた修正係数 $r_{f}(q), r_{s}(q)$ を風洞実験により求めるための手順は以下の 通りである。

Step 1 ：適当な設計点 $q=q_{d}$ を選択してコントローラ $K(s)$ を設計する.

Step $2: K(s)$ を用いてフラッタ制御風洞実験を行い, 制 御時のフラッタ動圧を計測する。このとき，コントロー ラはその出力ゲインを変化させて制御実験を行う. 出力 ゲインを $K_{c}$ とすると， $K_{c} K(s)$ を風洞実験用コントロ ーラとして扱う. 本研究では,

$$
K_{c}=0.25,0.50,0.75,1.00
$$

の 4 種類のゲインを用いた。

Step $3:$ LPV システム $(7)$ 式に $K c K(s)$ を用いて構成し た閉ループ系の安定限界が、風洞実験でのフラッタ動圧 と一致するように修正係数 $r_{f}(q), r_{s}(q)$ を決定する. $(7)$ 式は $r_{f}(q)$ の增加または $r_{s}(q)$ の減少により閉ルー プ系が不安定側に遷移するので，適当な初期值を設定し て安定限界となる修正係数を実験で得られたフラッタ動 压に対して探索する。

これらのプロセスを複数のコントローラで評価し，コント ローラに偖存しない修正係数決定法をモデル修正に採用す る.このときのコントローラ設計は，修正前のプラントモ デルを用いて $H_{\infty}$ 制御法のロバスト安定化問題 (4.1 節参

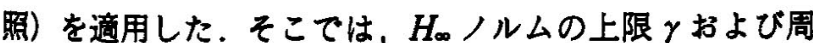
波数依存重みのパラメータを変えて 4 種類のコントローラ $\left(K_{1}, \cdots, K_{4}\right)$ を設計した。

3.3 風洞実験と修正係数 風洞実験は，航空宇宙技術 研究所の遷音速風洞で行った。翼を風洞内部の天井から吊 り下げて取り付けた（上流から下流を見た）状態の遷音速 風洞の写真を第 2 図に示す，第 3 図に計測制御システムの 概略を示す. 翼模型に取り付けた加速度計の出力をアンチ

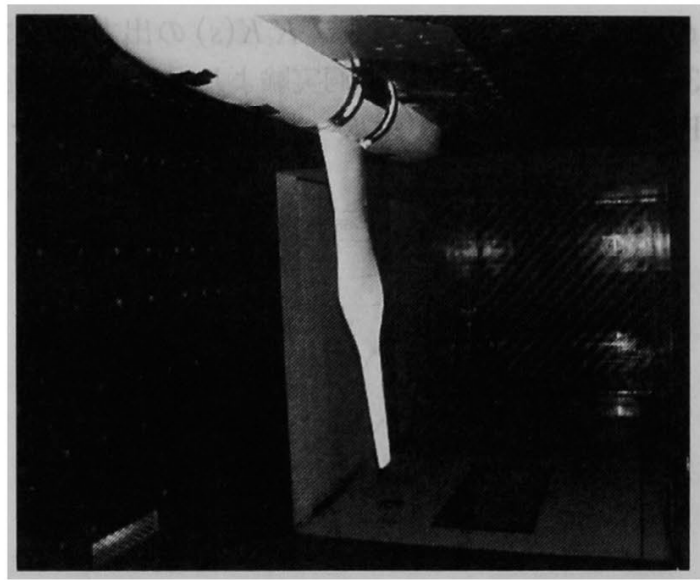

第 2 図 遷音速風洞と高アスペクト比翼

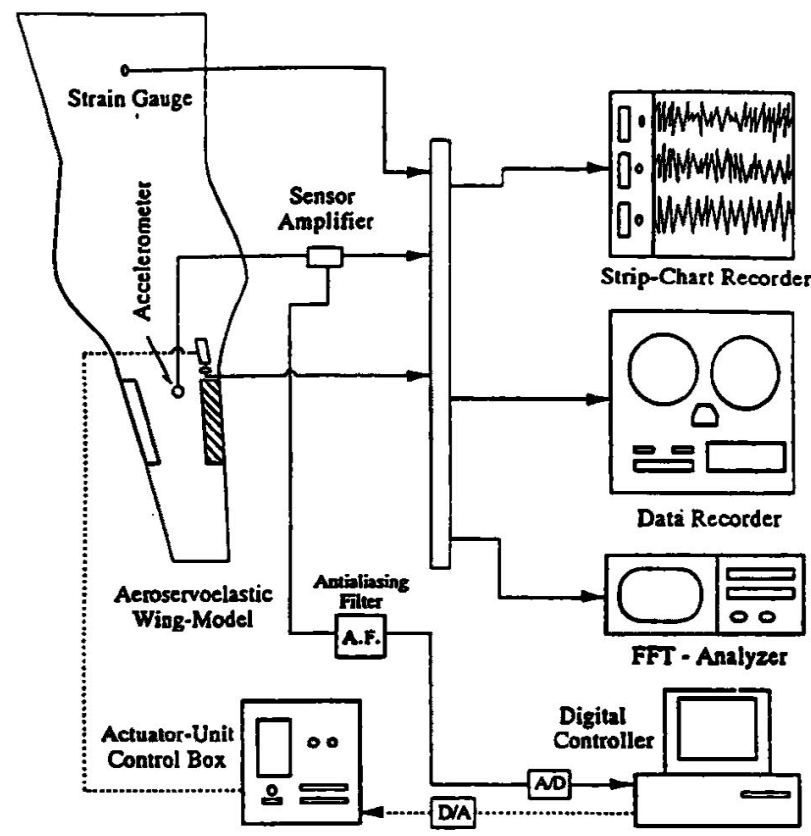

第3 図 フラッタ制御実験計測制御システム

エリアッシングフィルタと $\mathrm{A} / \mathrm{D}$ 変換器を介してディジタ ルコンピュータに取り込み, 後縁舵面の制御入力 $u(t)=$ $\delta_{c}(t)$ が $K_{c} K(s)$ を Tustin 変換により離散化した制御則に 基づき計算する。 それを $\mathrm{D} / \mathrm{A}$ 変換器を介してアクチュエ ータュニット制御ボックスに入力して後緑舵面を駆動す る.これら一連の信号の入出力は $500[\mathrm{~Hz}]$ のサンプリン グ周波数で行った。 なお, 加速度計や後緑舵面の舵角，翼 根付近の歪 $\varepsilon_{B 1}$ をデータレコーダに記録するとともに、ペ ンレコーダ (Strip-Chart Recorder) および FFT アナラ イザでモニタリングした.

実験条件は，マッ八数を 0.8 と固定し，動圧を約 23〜29 [kPa]の範囲で変動させてフラッタが発生する環 境を設定した*6.なお，制御 OFFでのフラッタ動圧は $q_{f_{0}}$ $=25.40[\mathrm{kPa}]$ であった.

第 4〜7図に動圧に依存した修正係数の変化を示す。こ

${ }^{* 6}$ 実験では風洞内の総圧を操作している. 
れらのグラフは，コントローラ $K_{c} K(s)$ の出カゲイン $K_{c}$ を(13)式のように変えて, 風洞実験より得たフラッタ動圧 と LPV システム (7)式の閉ループ系の安定限界がー致す

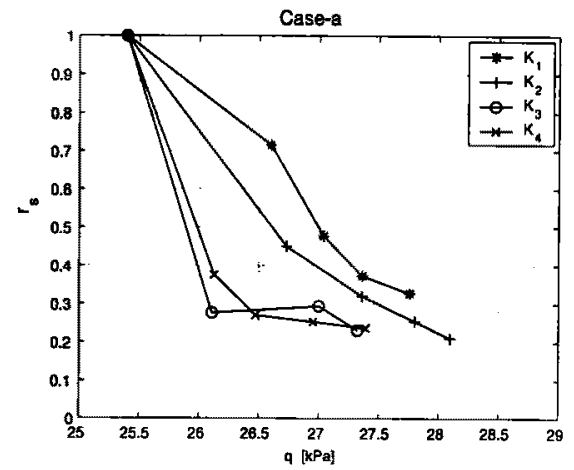

第 4 図 修正係数 $r_{s}(q)$, Case-a

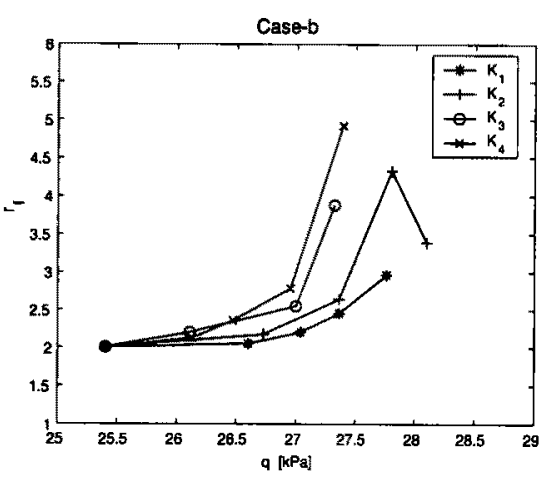

第 5 図 修正係数 $r_{f}(q)$, Case-b

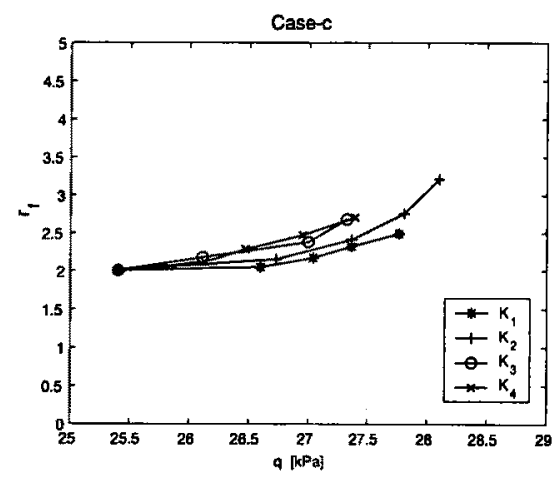

第 6 図 修正係数 $r_{f}(q)$, Case-c

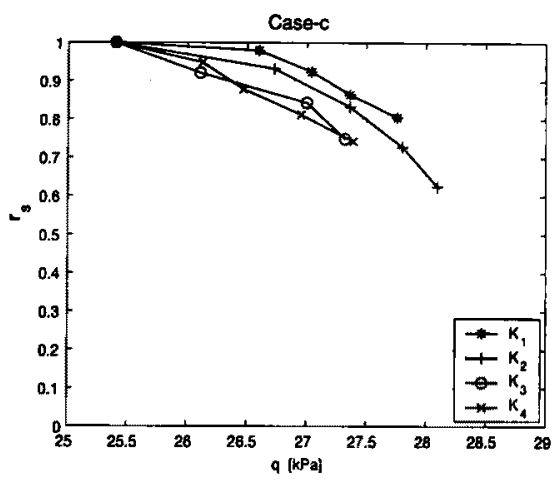

第 7 図 修正係数 $r_{\mathrm{s}}(q)$, Case-c
るように修正係数 $r_{f}(q), r_{s}(q)$ を求めたものをコントロ 一ラ毎にグラフ化したものである。ただし，制御 OFFて

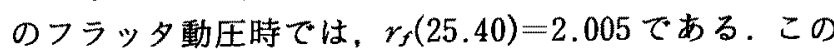
ときは後縁舵面を使用しないので， $r_{s}(25.40)=1$ と与え

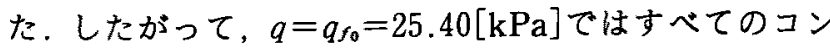
トローラは同一の值をとることになる。また，コントロー ラ $K_{3}$ は $K_{c}=1.00$ での風洞実験中に発振したため, フラ ッタ動圧が計測できなかったので他よりも1つプロット点 が少ない，どのケースにおいても，線形モデルを実際のフ ラッタ動圧と一致させるには, 動圧の変化に応じて $r_{f}(q), r_{s}(q)$ を変える必要があることがわかる．第 4〜7 図を比較すると，4 種類のコントローラによる曲線の合致 度が高いのは，Case-cである．したがって，本研究では Case-c の修正係数決定法を線形モデルの修正法として採 用する.第 6 図に示された修正係数 $r_{f}(q), r_{s}(q)$ の近似 曲線関数を求めておけば，任意の動圧に対しての係数を得 ることができる，そこで，第 6 図の結果を最小二乗法によ って内挿近似する。．その近似曲線 $r_{f}(q)$ は

$$
r_{f}(q)=1.1509 \times 10^{-4} q^{3}+3.002 \times 10^{-2}
$$

と求められる。なお， $r_{s}(q)$ は(14)式を(12) 式に代入する ことにより得られる。

\section{4. 能動フラッタ抑止（AFS）}

前節で求めた修正係数を使った LPV システム $(7)$ 式を 用いて，AFS コントローラを再度設計し，モデル修正の 効果とコントローラの制御性能を線形モデルおよび風洞実 験で検討する。

4.1 コントローラの設計 前節の結果より, Case-c の修正係数決定法が最も妥当であったことから，(12)， (14)式を用いて LPVモデル（7)式を修正した. AFS コ ントローラを, $H_{\infty}$ 制御のロバスト安定化問題の定式化に 基づいて設計した。すなわち，設計モデル $P(s)$ を $\Sigma\left(q_{d}\right)$ とし，それより動圧が高い摄動モデル $\bar{P}(s)$ を $\Sigma\left(q_{e}\right)\left(q_{e}\right.$ $\left.>q_{d}\right)$ としたとき， $\tilde{P}(s)$ は乗法的モデルの不確かさ $\Delta_{m}(s)$ および加法的モデルの不確かさ $\Delta_{a}(s)$ を含んで

$$
\begin{aligned}
\widetilde{P}(s) & =\left(1+\Delta_{m}(s)\right) P(s) \\
& =P(s)+\Delta_{a}(s)
\end{aligned}
$$

と表現できる． $\Delta_{m}(s)$ または $\Delta_{a}(s)$ は，次式に示すように 有理関数 $W_{m}(s), W_{a}(s)$ でその上限值を与えることがで きる。

$\left|\Delta_{m}(j \omega)\right|<\left|W_{m}(j \omega)\right|$ for $\forall \omega$

$$
\left|\Delta_{a}(j \omega)\right|<\left|W_{a}(j \omega)\right| \text { for } \forall \omega
$$

これらを用いることにより， $H_{\infty}$ 制御のロバスト安定化問 題はそれそれれ

$$
\begin{aligned}
& \left\|W_{m} P K(I+P K)^{-1}\right\|_{\infty}<\gamma \\
& \left\|W_{a} K(I+P K)^{-1}\right\|_{\infty}<\gamma
\end{aligned}
$$

を満たす安定化コントローラ $K(s)$ を求める問題とな

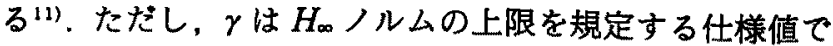
ある. 以後, 前者のコントローラを $K_{m}$ ，後者を $K_{a}$ と記 す．これらのコントローラはプラントの次数に加えて，有 理関数 $W_{m}(s), W_{a}(s)$ の次数が加わるので高次元系とな 
ってしまう.サンプリング周波数 $500[\mathrm{~Hz}]$ 以内て信号の 入出力および制御入力の計算を行うためには、フラッタ制 御実験で使用するディジタルコンピュータの演算速度の制 約から，コントローラの次数を 8 次元以下に低隇する必要 がある，そこで本研究では，著者の一人である藤森がこれ までに検討してきた有力なコントローラ低次元化法の $1 つ$ てある既約分解表現を用いた周波数低存重み付きコントロ ーラ低次元化の㹡張 (ECFW) 法 ${ }^{12)}$ 用いて, コントロ 一ラの次数を 8 次元に低次元化した。詳細は文献 12)を参 照されたい.

4.2 コントローラの特性 一例として, $q_{d}=1.15 q_{f_{0}}$, $q_{e}=1.25 q_{f_{0}}\left(q_{f_{0}}\right.$ は開ループ系のフラッタ動圧で $q_{f_{0}}=$ $25.40[\mathrm{kPa}])$ で設計したときのコントローラの周波数応 答を第 8 図に示す. $K_{m}$ は $K_{a}$ に比べて低周波でグインが 大きくなっているのに対し $40[\mathrm{~Hz}]$ から $800[\mathrm{~Hz}] に か$ けては逆に $K_{a}$ のゲインが大きい特性を示している. 設計 されたコントローラのロバスト性を評価するために，相補

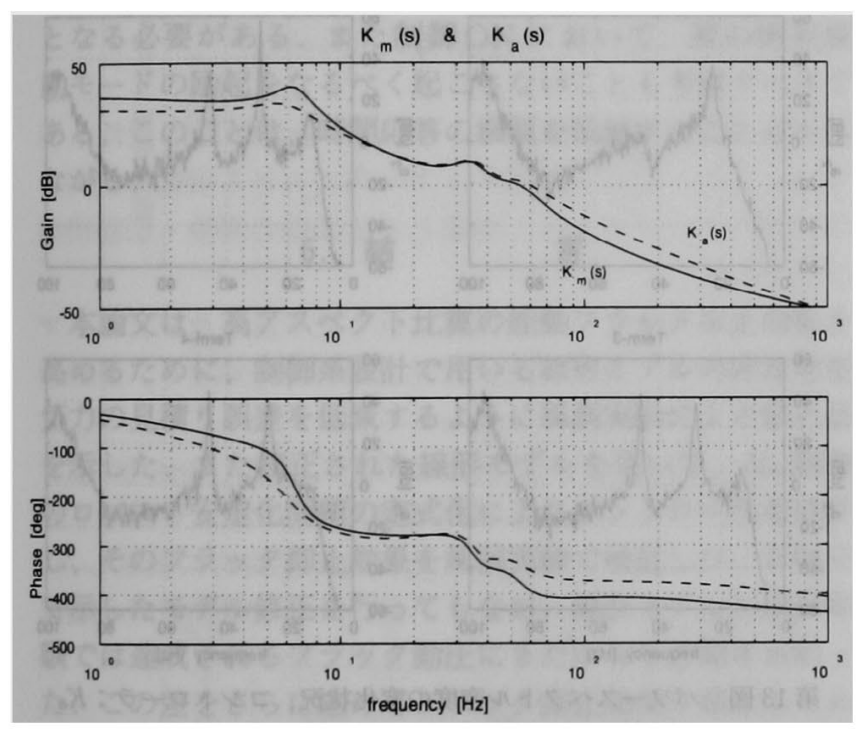

第 8 図 コントローラの周波数応答

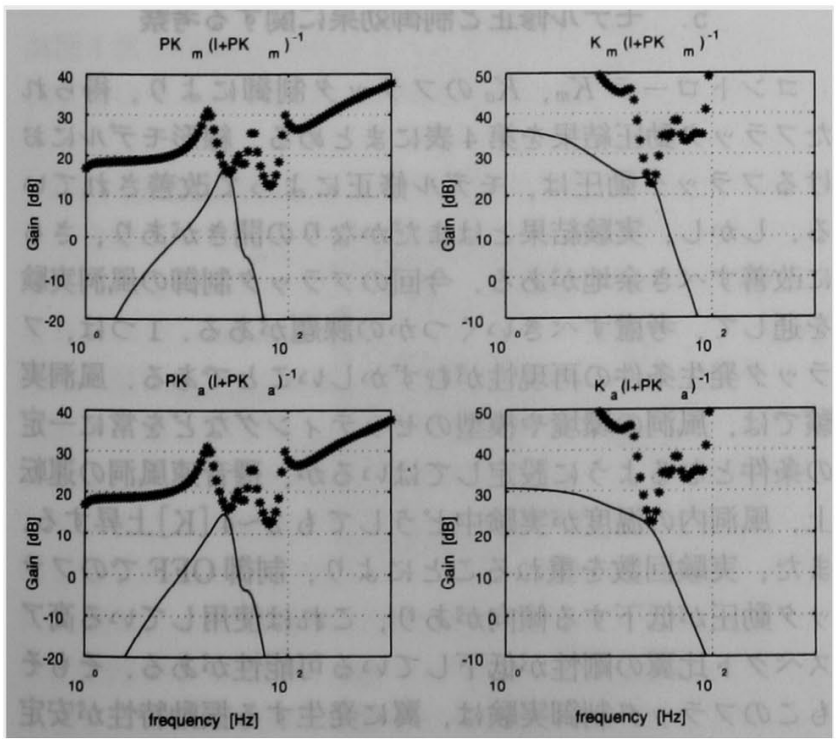

(u)

第 9 図 相補感度行列と萑相補感度行列
感度行列 $P K(I+P K)^{-1}$ および準相補感度行列 $K(I$ $+P K)^{-1}$ の特異值線図を第 9 図に示す。同図には，摄動 プラントモデル $\Sigma\left(q_{e}\right)$ を安定化する（ロバスト安定）条 件式

$$
\bar{\sigma}\left[P K(I+P K)^{-1}(j \omega)\right]<1 / \bar{\sigma}\left[\Delta_{m}(j \omega)\right] \text { for } \forall \omega
$$

$\bar{\sigma}\left[K(I+P K)^{-1}(j \omega)\right]<1 / \bar{\sigma}\left[\Delta_{a}(j \omega)\right]$ for $\forall \omega(22)$ の上限值を‘”’で示している. $K_{a}$ のほうが $K_{m}$ よりわず かではあるがロバスト安定性が高いといえる.

4.3 フラッタ制御実験 設計したコントローラの性能 をフラッタ制御の風洞実験によって評価した。実験条件は 3.3 節の修正係数を決定するための風洞実験と同様，マッ 八数 $0.8 て ゙$ て行った．風洞実験は，マッ八数一定の下で動圧 $q$ を上昇させてフラッタの発生する環境を設定した。第 10,11 図は，それぞれコントローラ $K_{m}, K_{a}$ を用いたとき の動圧 $q$, 翼根の歪 $\varepsilon_{B 1}$, 加速度 $a_{2}$ および後縁舵面 $\delta_{2}$ の 時間応答である. 制御 OFF のフラッタ動圧はこの風洞実

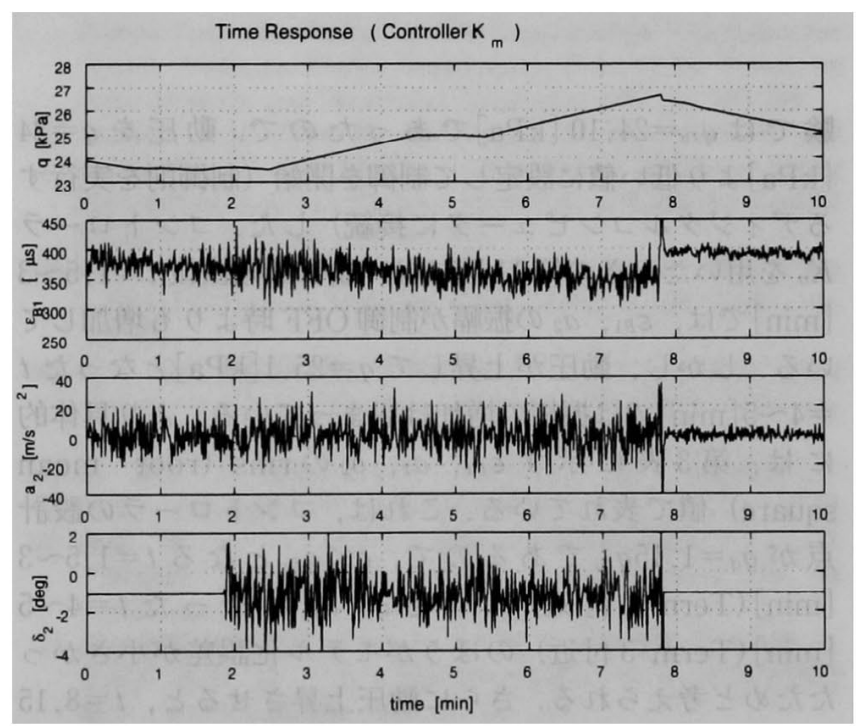

第 10 図 フラッタ制御実験の時間応答, コントローラ： $K_{m}$

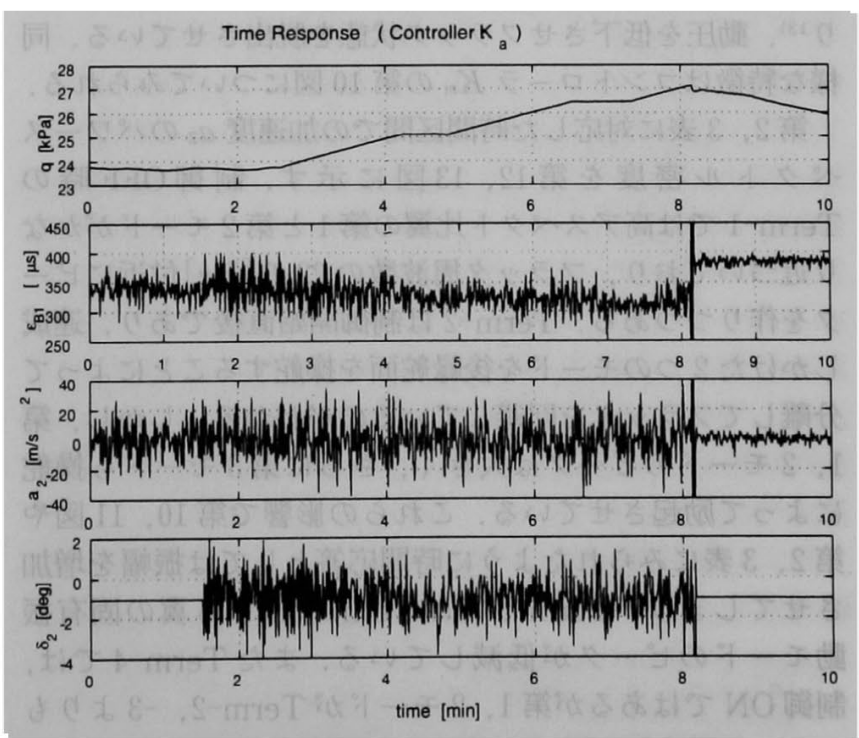

第 11 図 フラッタ制御実験の時間応答、コントローラ：Ka 
第 2 表 フラッタ制御実験の rms 值・、コントロー

\begin{tabular}{cccl} 
ラ: $K_{m}$ & & & \\
\hline $\begin{array}{c}\text { 時間区間 } \\
(\mathrm{min})\end{array}$ & $\begin{array}{c}\varepsilon_{\boldsymbol{B} 1} \\
(\mu \mathrm{s})\end{array}$ & $\begin{array}{c}a_{2} \\
\left(\mathrm{~m} / \mathrm{s}^{2}\right)\end{array}$ & $\begin{array}{c}\delta_{2} \\
(\mathrm{deg})\end{array}$ \\
\hline Term-1 $(1.5)$ & 14.625 & $\mathbf{9 . 5 3 2}$ & 0 \\
Term-2 $(2.2)$ & 22.977 & 10.194 & 1.4750 \\
Term-3 $(4.5)$ & 16.614 & 10.162 & 0.9334 \\
Term-4 $(7.5)$ & 21.550 & 12.493 & 1.0960 \\
\hline
\end{tabular}

*rms值は，Timeの括张内で示す時刻から 10 [s]間の計測データによるものでる。

第 3 表 フラッタ制御実験の rms 值*,コントロー ラ: $K_{a}$

\begin{tabular}{cccc}
\hline $\begin{array}{c}\text { 時間区間 } \\
(\mathrm{min})\end{array}$ & $\begin{array}{c}\varepsilon_{B_{1}} \\
(\mu \mathrm{s})\end{array}$ & $\begin{array}{c}a_{2} \\
\left(\mathrm{~m} / \mathrm{s}^{2}\right)\end{array}$ & $\begin{array}{c}\delta_{2} \\
(\mathrm{deg})\end{array}$ \\
\hline Term-1 (1.0) & 17.643 & 10.721 & 0 \\
Term-2 (1.7) & 30.138 & 12.658 & 1.4913 \\
Term-3 (4.4) & 19.044 & 10.753 & 0.9265 \\
Term-4 (7.9) & 23.599 & 13.402 & 1.1721 \\
\hline
\end{tabular}

"rms值は，Timeの括抔内で示す時刻から 10

[s]間の計測データによるものである。

験では $q_{f_{0}}=24.10[\mathrm{kPa}] て ゙$ あたので, 動圧を $q=24$ $[\mathrm{kPa}]$ より低い值に設定して制御を開始（制御則を実行す るディジタルコンピュータに接続）した。コントローラ $K_{a}$ を用いたときの第 11 図では, 制御開始直後 $t=1.5 \sim 3$ [min]では， $\varepsilon_{B 1}, a_{2}$ の振幅が制御 OFF 時よりも增加して いる.しかし、動圧が上昇して $q=25.1[\mathrm{kPa}]$ となった $t$ $=4 \sim 5[\mathrm{~min}]$ ては振幅の増加は収まっている.より具体的 には，第 3 表に示す $\varepsilon_{B 1}, a_{2}, \delta_{2}$ の rms (root mean square）值で表れている。これは、コントローラの設計 点が $q_{d}=1.15 q_{f_{0}}$ であるので，q< $q_{f_{0}}$ となる $t=1.5 \sim 3$ [min] (Term-2 付近) よりも $q>q_{s_{0}}$ となった $t=4 \sim 5$ [min] (Term-3 付近) のほうがモデル化誤差が小さかつ たためと考えられる。ささらに動圧上昇させると， $t=8.15$

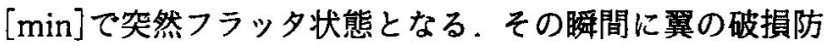
止用のフラッタ停止板を風洞内で立ち上げることによ $\eta^{13)}$ ，動圧を低下させフラッ夕状悲を脱出させている. 同 様な特徵はコントローラ $K_{m}$ の第 10 図についてみられる.

第 2，3 表に対応した時間区間での加速度 $a_{2}$ のパワース ペクトル密度を第 12,13 図に示す。制御 OFF 時の Term-1 では高アスペクト比翼の第 1 と第 2 モードがかな り近づいており，フラッタ周波数の $22.6[\mathrm{~Hz}]$ 付近にピー クを作りつつある. Term-2 は制御開始直後であり，連成

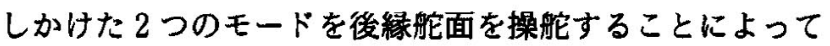
分離してフラッタを回避しているのがわかる。 しかし，第

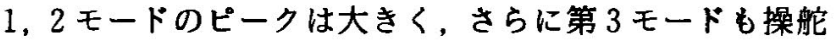
によって励起させている。これらの影響で第 10,11 図や 第 2,3 表にみられたように時間応答としては振幅を增加 させてしまう. Term-3では Term-2よりも翼の固有振 動モードのピークが低隇している．またTerm-4では， 制御 ONではあるが第 1，2モードが Term-2，-3よりも フラッタ周波数に近づいているのが観察される。
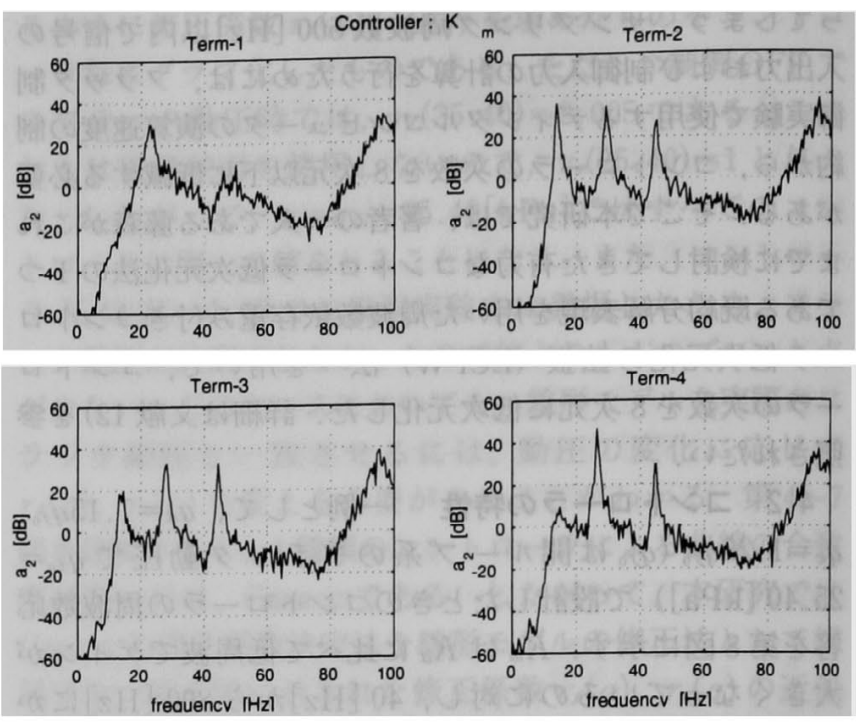

第 12 図 パワースペクトル密度の変化状況，コントローラ： $K_{m}$
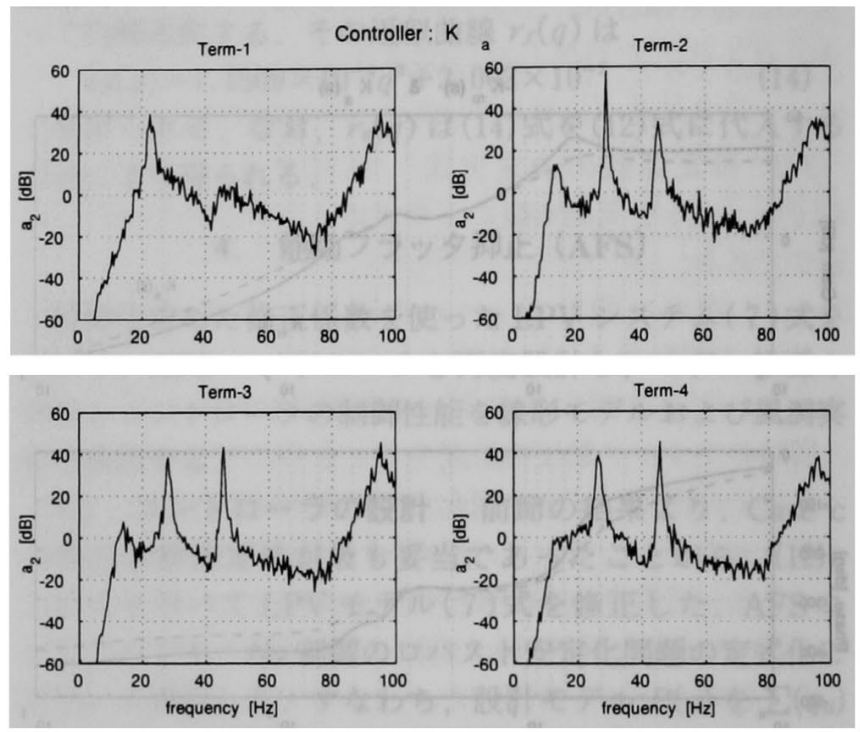

第 13 図 パワースペクトル密度の変化状況，コントローラ：Ka

\section{5. モデル修正と制御効果に関する考察}

コントローラ $K_{m}, K_{a}$ のフラッタ制御により，得られ たフラッタ勳圧結果を第 4 表にまとめる。線形モデルにお けるフラッタ動圧は，モデル修正によって改善されてい る、しかし，実験結果とはまたかなりの開きがあり，さら に改善すべき余地がある．今回のフラッタ制御の風洞実験 を通して，考慮すべきいくつかの課題がある．1つは，フ ラッタ発生条件の再現性がむずかしいことである，風洞実 験では，風洞の環境や模型のセッティングなどを常に一定 の条件となるように設定してはいるが，遷音速風洞の運転 上，風洞内の温度が実験中どうしても 2〜4 [K] 上昇する. また，実験回数を重ねることにより，制御 OFFでのフラ ッタ動圧が低下する傾向があり，これは使用している高ア スペクト比翼の剛性が低下している可能性がある。そもそ もこのフラッタ制御実験は、翼に発生する振動特性が安定 振動から不安定振動に変わる臨界状態を扱うのて，上記の 
第 4 表 フラッタ制御時のフラッタ動圧

\begin{tabular}{|c|c|c|c|}
\hline \multirow{2}{*}{ コントローラ } & \multicolumn{2}{|c|}{ 線形モデル $q_{f_{0}}=25.40[\mathrm{kPa}]$} & \multirow{2}{*}{$\begin{array}{c}\text { 風 洞 実験 } \\
a_{f_{0}}=24.10[\mathrm{kPa}]\end{array}$} \\
\hline & 徏正前 & 修正 後 & \\
\hline$K$ & $80(37.0 \%$ & $30.48(20$. & $26.77(9.6 \%)$ \\
\hline$K_{a}$ & $37.85(49.0 \%)$ & $31.00(22.0 \%)$ & $27.10(12.1 \%)$ \\
\hline
\end{tabular}

括弧内の值は制御 OFF からのフラッタ動圧の上昇率を示す.

防ぎきれない実験条件の微妙な変化が制御結果に影響して しまう。

もうひとつの課題として, 制御入力振幅を考慮する必要 がある.使用したモータは振幅依存の周波数特性があり, 操舵振幅が大きくなるとモー夕の固有周波数が低下する傾 向がある7).また，モー夕の安全上，過大振幅に対してモ 一タがロックするように制御回路が作動する、操舵振幅が 大きいときは駆動系のモデル化愦差が大きくなることに伴 い，制御性能の低下や舵のロックにより制御不能状態に陥 る傾向が強まる。したがって，フラッタ制御に用いるコン トローラはモータのロックを回避しかつ、駆動系モデルの 固有周波数の低下をできるだけ無視できる範囲の出力特性

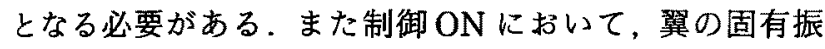
動モードの励起をなるべく起こさないことも考慮すべきで ある.このことは, 時間応答の振幅を低減することにもつ ながる。

\section{6. 結}

言

本論文は, 高アスペクト比翼の能動フラッタ抑止効果を 高めるために，制御系設計で用いる線形モデルの非定常空 気力の見積り誤差を低隇するように風洞実験による修正法 を示した．また修正された線形モデルを用いて， $H_{\infty}$ 制御 のロバスト安定化問題の定式化によりコントローラを設計 し，そのフラッタ抑止効果を風洞実験で検証した．本論文 でホしたモデル修正を行ってもなお，線形モデルと風洞実 験では達成されるフラッタ動圧にまだかなりの開きが残つ た。この差をさらに縮めてフラッ夕抑止効果を高めるため には、実験条件の変動への対処は難しいものの, 制御系設
計において，制御入力制限を考慮することやコントローラ の周波数特性を改良することが必要であり今後の課題であ 3.

\section{参考 文 献}

1) Quinton, P. P.: Future SSTs; A European Approach, Aerospace America, Sept. (1994), pp. 38-43.

2) Willams, L. J. : HSCT Research Gathers Speed, Aerospace America, Apr. (1995), pp. 32-37.

3）坂田公夫：実験機設計開発の進歩について, 次世代超音速機技術 及び航空安全環境適合技術に関する研究報告会, 1997, pp. 2-5.

4) Yoshida, T., Tsutsui, H., Takahashi, K. and Sanda, T.: Application of Active Control Technologies and Structural Optimization for Supersonic Commercial Transport, Proc. of World Aviation Congress, Los Angeles, 1996, pp. 1-9.

5) Saitoh, K., Matsushita, H., Hashidate, M. and Baldelli, D. H. : Active Flutter Suppression of a Flexible Wing in Transonic Region, Proc. of Int. Forum on Aeroelasticity and Structural Dynamics, 1994, pp. 581-586.

6）齊藤硉一，松下 洸，外立政隆，鈴木弘一，安藤泰勝：高アスペク 卜比翼遷音速フラッタのアクティブ制御, 第 34 回飛行機シンポ ジウム講演集, 1996, pp. 533-536.

7) Saitoh, K., Baldelli, D. H., Matsushita, H. and Hashidate, M. Robust Controller Design and Its Experimental Validation for Active Transonic Flutter Suppression, Proc. of Int. Forum on Aeroelasticity and Structural Dynamics, 1997, pp. 393-399.

8) Baldelli, D. H., Ohta, H., Matsushita, H., Hashidate, M. and Saitoh, K.: Flutter Margin Augmentation Synthesis Using Normalized Coprime Factors Approach, J. Guidance Control Dynamics, 18 (1995), pp. 802-811.

9) Ueda, T. and Dowell, E. H. : A New Solution Method for Lifting Surfaces in Subsonic Flow, AIAA J., 20 (1982), pp. 348-355.

10）松下 洸：弾性航空機の有限次元モデリングと LQG 制御, SICE セミナーテキスト(実システムのモデリングと制御)，1994, pp. $1-16$.

11）原 辰次：Ho制御によるサーボ系の設計, SICE 基䃈講習会テ キス卜 ( $H_{\infty}$ 制御入門), 計測自勳制御学会, 東京, 1991, pp. 49-72.

12) 藤森篤：ロバスト安定性を考慮した補償器の低次元化と二次 元翼能動フラッタ抑止采への応用，日本航空宇宙学会誌，41 (1993), pp. 88-95.

13）菊池孝男, 荁場重男, 鈴木誠三, 室田勝一, 安藤泰勝, 外立政隆, 上 田哲彦，松下 咣：フラッタ緊急停止装置について, 第 24 回飛行 機シンポジウム講演集, 1986, pp. 358-361. 